\title{
TEMPORAL PROCESSING IN MUSICIANS AND NON-MUSICIANS
}

\author{
Priyanka Vijaya Kumar, Baljeet Rana, Rajalakshmi Krishna
}

Department of Audiology, All India Institute of Speech and Hearing, Manasagangothri, Mysore, India

Corresponding author: Priyanka Vijaya Kumar, Department of Audiology, All India Institute of Speech and Hearing, Manasagangothri, Mysore - 570006, India, Tel: +91 9886801509, e-mail: priyanka.vishu@gmail.com

\begin{abstract}
Background: Temporal processing abilities are important for speech perception, and they are generally superior in musicians than in non-musicians. Since there are many different training methods used to develop musical expertise (e.g. vocal or instrumental), these differences could lead to varying temporal processing abilities of acoustic signals. The current study aims to see if there are any differences in temporal processing abilities between violinists and vocalists.
\end{abstract}

Material and Methods: Four different psychoacoustic tests - gap detection threshold (GDT), duration discrimination test (DDT), duration pattern test (DPT), and the modulation detection threshold for sinusoidally amplitude-modulated noise $(\mathrm{SAM})$ at six different modulation frequencies - were used to assess differences in temporal processing abilities between 15 trained violinists and 15 trained vocalists. The results were compared with a group of 15 non-musicians.

Results: Musicians, both violinists and vocalists, always performed significantly better $(p<0.01)$ than non-musicians in all 4 psychoacoustic tests. Vocalists performed equal to or slightly better than violinists in GDT and at 5/6 modulation frequencies in modulation detection threshold for SAM noise test, although the differences were not statistically significant.

Conclusions: Although vocalists and instrumentalists undergo different forms of training in terms of the sound they produce and the sound qualities they need to perceive, the training does not lead to any major difference in their temporal processing abilities of acoustic signals.

Keywords: music • psychoacoustics $\bullet$ speech perception $\bullet$ noise

\section{PROCESAMIENTO DE LA ESTRUCTURA TEMPORAL DE LA SEÑAL EN MÚSICOS Y NO-MÚSICOS}

\section{Resumen}

Introducción: La habilidad de procesamiento de la estructura temporal de la señal es importante en el proceso de la diferenciación del habla, y, por lo general, está más desarrollada en los músicos que en otras personas. Dado que existen varios métodos de entrenamiento, utilizados en el desarrollo de las habilidades músicas (p.ej. vocales o instrumentales), las diferencias entre ellos pueden llevar a la diferenciación de las habilidades del procesamiento de la estructura temporal de las señales acústicas. El objetivo del presente estudio es comprobar si existen diferencias en el procesamiento de la estructura temporal de la señal entre los violinistas y cantantes.

Material y métodos: Se han realizado cuatro diferentes pruebas psicoacústicas- prueba de detección aleatoria de las brechas (GDT), prueba de dígitos dicóticos (DDT), prueba de patrones temporales (DPT), prueba de detección de umbrales de modulación para los ruidos de una amplitud modulada de forma sinusoidal (SAM) para seis frecuencias de modulación diferentes. El objetivo de estas pruebas ha sido la evaluación de las diferencias en las capacidades de procesamiento de la estructura temporal de la señal, entre 15 violinistas y 15 cantantes profesionales. Los resultados se han comparado con los resultados de los no- músicos.

Resultados: Los músicos, tanto los violinistas como y cantantes, han obtenido unos resultados mucho mejores $(p<0.01)$ que los no-músicos en todas las 9 pruebas psicoacústicas. Los resultados de los cantantes han sido iguales con las pruebas de los violinistas o ligeramente mejores en 6 de las 9 pruebas psicoacústicas, aunque las diferencias no han sido estadísticamente relevantes.

Conclusiones: Aunque las formas de entrenamiento relacionado con el sonido y su calidad son distintas en caso de los cantantes y de los instrumentalistas, en efecto estas no afectan de forma significativa las diferencias en la habilidad del procesamiento de la estructura temporal de la señal acústica.

Palabras clave: procesamiento de la estructura temporal de la señal • violinistas $\bullet$ cantantes 


\section{ПРЕОБРАЗОВАНИЕ ВРЕМЕННОЙ СТРУКТУРЫ СИГНАЛА У МУЗЫКАНТОВ И НЕМУЗЫКАНТОВ}

\section{Изложение}

Введение: Умения преобразовывать временную структуру сигнала являются важными по вопросу различения речи, обычно они более развиты у музыкантов чем у других людей. Поскольку существует много методов тренинга, использованных для развития музыкальных умений (нап. вокальных или инструментальных), разница между ними может вести к дифференциации умений преобразовывать временную структуру акустических сигналов. Целью работы является проверка, существуют ли различия в преобразовании временной структуры сигнала у скрипачей и вокалистов.

Материал и методы: Проведено четыре разные психоакустические теста - тест на обнаружение интервалов в шуме (GDT), тест временных разниц (DDT), тест временных образцов (DPT), тест на обнаружение порогов модуляции для шумов с синусоидальной модулированной амплитудой (SAM) для шести разных частот модуляции. Целью тестов являлась оценка разниц в возможностях преобразования временной структуры между 15 профессиональными скрипачами и 15 профессиональными вокалистами. Результаты были сравнены с результатами людей, которые не являлись музыкантами.

Результаты: Музыканты, как скрипачи, так и вокалисты, имели значительно лучшие результаты $(p<0.01)$ чем люди, которые не были музыкантами во всех 9 психоакустических тестах. Результаты вокалистов были равны результатам скрипачей или немного лучше в 6 из 9 психоакустических тестов, хотя эти различия не были статистически существенными.

Итоги: Несмотря на то, что вокалисты и инструменталисты проходят разные формы тренинга в области звука, которым занимаются, и качества звука, к которому стремятся, в итоге это не влияет значительно на разницу в умениях преобразовывать временную структуру акустического сигнала.

Ключевые слова: обработка временной структуры сигнала • скрипачи • вокалисты

\section{PRZETWARZANIE STRUKTURY CZASOWEJ SYGNAŁU U MUZYKÓW I NIE-MUZYKÓW}

\section{Streszczenie}

Wprowadzenie: Umiejętności przetwarzania struktury czasowej sygnału są istotne w kwestii rozróżniania mowy i zwykle są bardziej rozwinięte u muzyków niż u innych osób. Jako, że istnieje wiele metod treningu stosowanych do rozwoju umiejętności muzycznych (np. wokalnych lub instrumentalnych), różnice między nimi mogą prowadzić do zróżnicowania umiejętności przetwarzania struktury czasowej sygnałów akustycznych. Celem pracy jest sprawdzenie czy istnieją różnice w przetwarzaniu struktury czasowej sygnału u skrzypków i wokalistów.

Materiał i metody: Przeprowadzono cztery różne testy psychoakustyczne - test na wykrywanie przerw w szumie (GDT), test różnic czasowych (DDT), test wzorców czasowych (DPT), test na wykrywanie progów modulacji dla szumów o sinusoidalnie modulowanej amplitudzie (SAM) dla sześciu różnych częstotliwości modulacji. Celem testów była ocena różnic w możliwościach przetwarzania struktury czasowej sygnału pomiędzy 15 zawodowymi skrzypkami i 15 zawodowymi wokalistami. Wyniki zostały porównane $\mathrm{z}$ wynikami osób nie będących muzykami.

Wyniki: Muzycy, zarówno skrzypkowie jak i wokaliści, mieli znacznie lepsze wyniki $(p<0.01)$ niż osoby nie będące muzykami we wszystkich 9 testach psychoakustycznych. Wyniki wokalistów były równe wynikom skrzypków lub nieco lepsze w 6 z 9 testów psychoakustycznych, choć te różnice nie były statystycznie istotne.

Wnioski: Mimo, że wokaliści i instrumentaliści przechodzą różne formy treningu w zakresie dźwięku, którym się zajmują, i jakości dźwięku, do którego dążą, w efekcie nie wpływają one znacząco na różnice w umiejętnościach przetwarzania struktury czasowej sygnału akustycznego.

Słowa kluczowe: przetwarzanie struktury czasowej sygnału • skrzypkowie • wokaliści 


\section{Background}

Temporal processing ability is the ability of an individual to process and perceive the time-related cues within an acoustic signal [1]. These cues are important for the perception of speech $[2,3]$ since speech is made up of a string of various sounds (consonants and vowels). Perception of these speech sounds depends upon recognizing characteristics such as place and manner of articulation. Production and perception of any speech sound involves a series of processes such as the movement of articulators and the encoding and decoding of the ensuing speech sounds. The processes involved provide cues which are necessary for decoding speech. The cues might relate to the intensity, frequency, or duration of an acoustic signal.

Temporal processing ability relates mostly to the processing of duration-related cues. For example, the production and perception of a stop consonant includes a series of processes that involve time-related cues such as closure duration, burst duration, transition, and voice onset timing [4-6]. Any small difference or change in the timing or duration of such cues can help differentiate various speech sounds. For instance, the duration of a burst is more for velar and shorter for bilabial stop consonants [7], and closure duration is greater for a labial place of articulation than a velar [8].

Temporal processing abilities have been reported to be superior in musicians compared to non-musicians [9-13]. Further, it is well established in the literature that musical training or musical exposure helps not only in fine tuning of auditory pathways but also helps preserve temporal resolution ability in the elderly hearing-impaired population [14].

Music is a universal language and has many types. There is much diversity across the world in terms of music genres and types of musicians. Basically, musicians can be classified either as vocal musicians (vocalists) or instrumental musicians (e.g. violinists, veena players, guitarists, etc.). Vocal musicians, also known as singers, are trained to produce and perceive detailed structures (e.g. variations in pitch, loudness, rhythm, melody, etc.) of chain of speech sounds with or without using an instrument. On the other side, instrumental musicians are trained mainly with the production and perception of non-verbal sounds using an instrument such as violin, guitar, veena, etc.

There are certain differences between vocal and instrumental music which mean that trainees undergo different experiences and perform different tasks. In general, most of the musical instruments tend to have high linear resonators: the role of these resonators for determining the frequency of produced sound vary from instrument to instrument [15]. Besides linear resonators, some instruments utilize non-linear resonators also. By the use of resonators it is possible for an instrument to produce a sound of particular frequency with sustained note which is completely independent of fluctuations in loudness and does not require much adjustments in other parameters. However, this seems to be slightly difficult in singing. Although human's vocal folds do exhibit linear resonators but they are not as high as in musical instruments, they might not have a complete control on the pitch of sounds $[15,16]$. Therefore in order to produce vocal sounds with sustained pitch, our vocal folds would require the adjustment of its other parameters. Furthermore, most of the sounds produced by an instrument might not contain a broad range of frequencies leading to its unnatural sound quality whereas speech sounds are usually broad band and hence sounds more natural, and are easily comprehensive [17].

Several studies have supported the fact that auditory processing of signals might differ depending on musical genre [18-20] although other studies contradict this [21]. In any case, research on vocal musicians is scarce, and comparisons of the temporal processing abilities between vocal and instrumental musicians have rarely been done. Since the exercises and tasks required in learning vocal music or instrumental music are different, we hypothesize that the complexity of auditory processes involved in learning and perceiving each musical form might also be different.

There is a lack of consensus among researchers regarding the different complexities involved in processing of acoustic signals from different music genres. Thus, the current study was conducted to compare, between instrumental musicians and vocalists, one among many auditory processes: the temporal processing of an acoustic signal. In addition we made efforts to compare temporal processing between musicians and non-musicians. The non-musician group was considered the reference group in order to control for variables such as age, method, and instrumental technique. Psychoacoustic studies suggest that musicians who tune their own instrument have better frequency discrimination than those who do not [22]. Among the string instruments used in Carnatic music (usually violin or veena), the violin with four strings was selected as it is the most commonly taught classical string instrument in Karnataka. Also, violin is a lead instrument that is similar to vocal music; hence violinists were selected for the study.

\section{Material and methods}

\section{Participants}

Exactly 15 professionally trained violinists, 15 professionally trained vocalists with more than 5 years experience in their areas of expertise (vocal or violin), and 15 non-musicians participated in the study. All participants were aged 18-45 years. A structured questionnaire was administered to ascertain the musical background and general health of participants. Questions covered basic information concerning age, education, working experience, medical history (middle ear disease, ear surgery, etc.), musical history (initiation age of training, form of musical training, musical proficiency, etc.), lifestyle (smoking, noisy hobbies, etc.), and their personal judgement of their own hearing status. Information regarding musical background is summarized in Table 1. Written consent was obtained from all participants and they were also informed of the complete test procedure and the approximate time needed for each test.

\section{Participant selection criteria}

All subjects were native Kannada speakers with normal air and bone conduction hearing thresholds $(\leq 15 \mathrm{~dB} \mathrm{HL})$ at 
Table 1. Musical background of violinists and vocalists

\begin{tabular}{|c|c|c|c|}
\hline Musicians & $\begin{array}{c}\text { Chronological age } \\
\text { (years) }\end{array}$ & $\begin{array}{l}\text { Initiation age of musical } \\
\text { training (years) }\end{array}$ & Musical proficiency \\
\hline Violinist 01 & 38 & 12 & Senior \\
\hline Violinist 02 & 19 & 9 & Junior \\
\hline Violinist 03 & 31 & 12 & Junior \\
\hline Violinist 04 & 20 & 10 & Junior \\
\hline Violinist 05 & 24 & 9 & Junior \\
\hline Violinist 06 & 39 & 11 & Senior \\
\hline Violinist 07 & 42 & 8 & Vidwath \\
\hline Violinist 08 & 29 & 11 & Senior \\
\hline Violinist 09 & 44 & 12 & Vidwath \\
\hline Violinist 10 & 27 & 11 & Junior \\
\hline Violinist 11 & 33 & 9 & Senior \\
\hline Violinist 12 & 40 & 8 & Vidwath \\
\hline Violinist 13 & 39 & 11 & Senior \\
\hline Violinist 14 & 22 & 7 & Junior \\
\hline Violinist 15 & 26 & 8 & Junior \\
\hline Vocalist 01 & 33 & 6 & Senior \\
\hline Vocalist 02 & 43 & 6 & Vidwath \\
\hline Vocalist 03 & 22 & 12 & Junior \\
\hline Vocalist 04 & 29 & 12 & Junior \\
\hline Vocalist 05 & 33 & 9 & Senior \\
\hline Vocalist 06 & 19 & 12 & Junior \\
\hline Vocalist 07 & 19 & 9 & Junior \\
\hline Vocalist 08 & 29 & 8 & Senior \\
\hline Vocalist 09 & 36 & 5 & Senior \\
\hline Vocalist 10 & 40 & 8 & Vidwath \\
\hline Vocalist 11 & 18 & 10 & Junior \\
\hline Vocalist 12 & 25 & 11 & Junior \\
\hline Vocalist 13 & 44 & 7 & Vidwath \\
\hline Vocalist 14 & 39 & 8 & Senior \\
\hline Vocalist 15 & 27 & 9 & Junior \\
\hline
\end{tabular}

There are 3 levels of proficiency in Carnatic music: a) Junior b) Senior, and c) Vidwath. Beginners start at Junior level and to move to the next level (i.e. Senior and then Vidwath) they have to pass exams conducted by the Karnataka Secondary Education Board.

octave frequencies from $250 \mathrm{~Hz}$ to $8 \mathrm{kHz}$ or $4 \mathrm{kHz}$ bilaterally; normal middle ear function (A-type tympanogram using a $226 \mathrm{~Hz}$ probe tone and normal acoustic reflexes in both ears); speech recognition threshold of $\pm 12 \mathrm{~dB}$ (re PTA of $0.5,1$, and $2 \mathrm{kHz}$ ) in both ears; speech identification scores (SIS) of more than $90 \%$ at $40 \mathrm{~dB}$ SL (re SRT); and with no illness on the day of testing. Participants with the presence/report of any neurologic or structural abnormality (ascertained by the researcher) were not considered.

\section{Test environment}

All tests were conducted in a sound-treated double room as per the standards of ANSI S3.1 (2003) [23]. 


\section{Procedure}

The complete procedure was divided into two phases:

Phase I

This phase included tests to ascertain normal hearing sensitivity in all subjects and took approximately 35 to $40 \mathrm{~min}$ utes. Pure tone air conduction and bone conduction thresholds were obtained using a modified version of the Hughson Westlake procedure [24] for octave frequencies from $250 \mathrm{~Hz}$ to $8 \mathrm{kHz}$ or $4 \mathrm{kHz}$. Confirmation of normal middle ear function was done using tympanometry and reflexometry with a GSI Tympstar middle ear analyzer (Grason-Stadler Inc, USA). Normal speech perception abilities and absence of any neurologic problems were confirmed by assessing the speech recognition threshold (SRT) using Kannada Spondee words [25] and speech identification scores (SIS) using the Kannada Phonemically Balanced (PB) word list [26].

Phase II

Only if a participant fulfilled all criteria for normal hearing sensitivity, as assessed using the tests in Phase I, was Phase II conducted. This phase consisted of four psychoacoustic tests assessing temporal processing abilities. These four tests (GDT, DDT, DPT, and modulation detection threshold for SAM noise at six different modulation frequencies, as listed below) were chosen because of their wide utilization and acceptance in the literature for assessing temporal processing ability. Moreover, they are easy to access and easy to conduct. All psychoacoustic tests were conducted monaurally in the ear with better thresholds. If a participant had symmetrical thresholds then the tests were conducted in the right ear. For all psychoacoustic tests the stimulus was presented at $40 \mathrm{~dB}$ SL with reference to PTA or at the most comfortable level using calibrated Sennheiser HAD 200 circumaural headphones. All psychoacoustic tests were conducted in the same order as listed below. After each test a 5-10 minute rest period was given to ensure that participants remained alert.

\section{Gap detection threshold (GDT)}

The GDT test consists of a standard stimulus of $750 \mathrm{~ms}$ duration Gaussian noise incorporating a standard duration silence at its temporal center. The stimulus noise had a 0.5 $\mathrm{ms}$ cosine ramp at both onset and offset. A three-interval alternate forced-choice method (3IAFC) was used. A single trial consisted of three blocks of noise, one of which contained a gap. The subjects were instructed to detect the block of noise with the gap and the length of the gap was changed as a function of the subject's performance. The minimum gap duration that the subject could detect was considered as the GDT. A staircase procedure run under Apex 3 software was used to provide an estimate of the $71 \%$ correct response level [27].

\section{Duration discrimination test (DDT)}

The DDT measures the minimum difference in duration required to perceive two otherwise identical stimuli. The standard stimulus was a pure tone of $250 \mathrm{~ms}$ and the duration of the variable tone was based on the responses of the subject. In a 3IAFC procedure, the subject was asked to nominate which interval contained the longer duration signal, in other words which signal (first, second, or third) was the longer. A staircase procedure run under Matlab R2010b software was used to provide an estimate of the $71 \%$ correct response level [27].

\section{Duration pattern test (DPT)}

The DPT consists of a $1000 \mathrm{~Hz}$ pure tone of two different durations [28]. The short duration tone was of $250 \mathrm{~ms}$ and the longer one was of $500 \mathrm{~ms}$. The DPT has six different patterns generated by combining these two durations with three different tone patterns (long-long-short, short-shortlong, long-short-long, short-long-long, short-long-short, long-short-short). The interstimulus interval was $250 \mathrm{~ms}$ within a sequence and there was a gap of $6 \mathrm{sec}$ between two tone sequences. The subjects were asked to respond by verbally repeating the sequence. After 5 practice trials, 30 test items were administered. Each correct response was given a score of 1 and each wrong response was given a score of 0 . Total scores out of 30 were considered.

Modulation detection thresholds for sinusoidally amplitude-modulated noise

Unmodulated and sinusoidally amplitude-modulated (SAM) Gaussian noise of 500 ms duration with a ramp of $20 \mathrm{~ms}$ was used as a stimulus. The SAM Gaussian noise was presented at six different modulation frequencies $(4,8,16$, 32,64 , and $128 \mathrm{~Hz}$ ), and modulation detection thresholds were estimated using the 3IAFC method. On each trial, two unmodulated and one modulated stimuli were successively presented with an interstimulus interval of $500 \mathrm{~ms}$. The subject's task was to indicate which interval contained the modulated noise. Modulation depth was varied between 0 to $-30 \mathrm{~dB}$ (where $0 \mathrm{~dB}$ had $100 \%$ modulation depth and $-30 \mathrm{~dB}$ had virtually no modulation). The minimum modulation depth needed to detect a modulated signal was considered to be the modulation detection threshold. Thirty trials were presented to each subject using the maximum likelihood procedure (MLP) toolbox [29] in Matlab R2010b.

\section{Statistical analysis}

The data was statistically analyzed using SPSS (version 18) software. Descriptive statistics (mean and standard deviation) were computed for all parameters. Further, MANOVA was administered between the three groups with scores of all the tests (GDT, DDT, DPT, SAM noise detection thresholds at six different modulation frequencies) as dependent variables.

\section{Results}

The results are reported separately for each test.

\section{Gap detection threshold (GDT)}

The mean and standard deviation (SD) of GDT for nonmusicians, violinists, and vocalists are shown in Figure 1.

MANOVA results revealed a statistically significant difference across the groups $[\mathrm{F}(2,42)=6.98, p<0.01]$. Duncan 


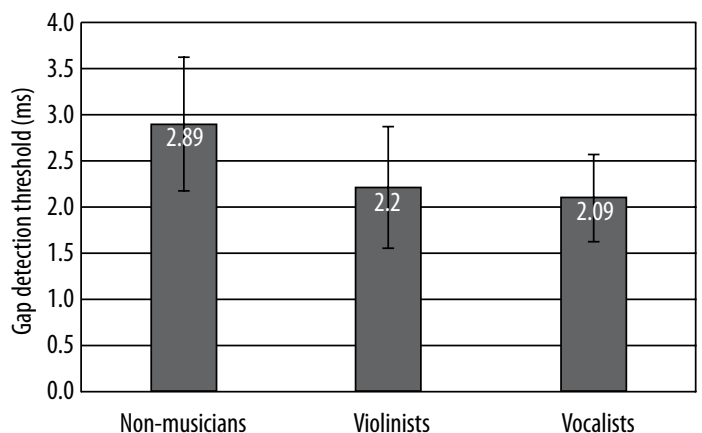

Figure 1. Mean gap detection thresholds ( \pm 1 SD) for nonmusicians, violinists, and vocalists

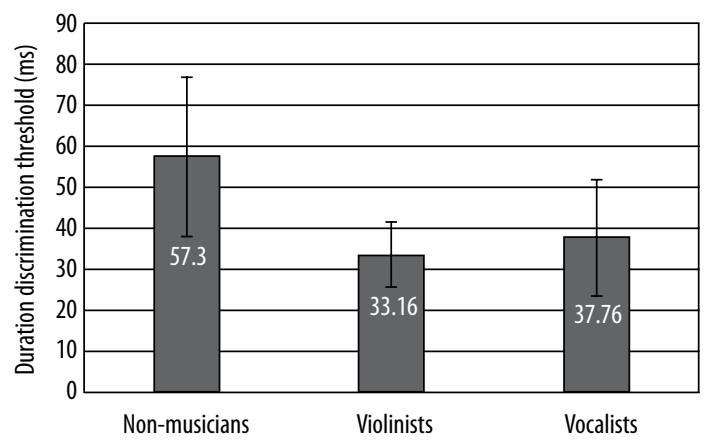

Figure 2. Mean duration discrimination thresholds ( \pm 1 SD) for non-musicians, violinists, and vocalists

post hoc analysis revealed a statistically significant difference between the musicians (violinists and vocalists) and non-musicians. However, no statistically significant difference was observed between the two musician groups (although Figure 1 shows that the GDT of vocalists was slightly better than that of violinists).

\section{Duration discrimination test (DDT)}

Figure 2 shows the DDT thresholds for all three groups. MANOVA results revealed that there is a statistically significant difference across the groups $[F(2,42)=11.33, p<0.01]$. Duncan post hoc analysis revealed no statistically significant difference between the violinists and the vocalists. However, a significant difference was observed between the musicians and the non-musicians.

Clearly, musicians performed better than non-musicians in this test (and now the violinists' DDT thresholds were slightly better than that of the vocalists).

\section{Duration pattern test (DPT)}

DPT scores for all the groups are shown in Figure 3. MANOVA results revealed a statistically significant difference across the groups $[F(2,42)=14.82, p<0.01]$. The Duncan post hoc test did not reveal any statistically significant difference between violinists and vocalists. However, there was a statistically significant difference between musicians and non-musicians. As can be observed from Figure 3, overall musicians performed better than

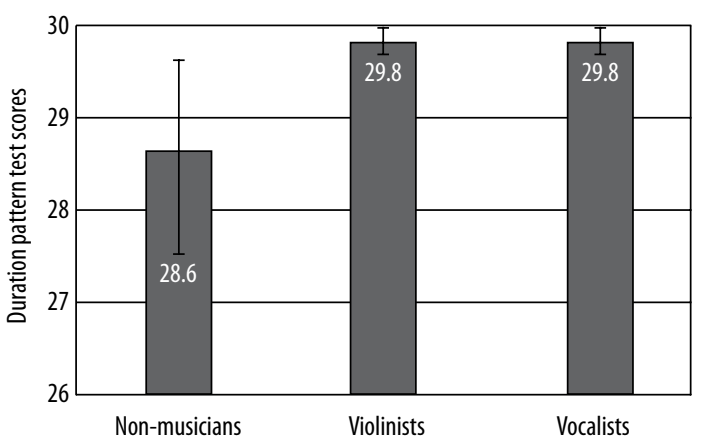

Figure 3. Mean duration pattern scores ( \pm 1 SD) for nonmusicians, violinists, and vocalists

non-musicians (and here violinists and vocalists were equally good).

Modulation detection thresholds for sinusoidally amplitude-modulated noise

Figure 4 shows modulation detection thresholds for SAM noise at six different modulation frequencies. Repeated measures ANOVA with modulation detection thresholds at different frequencies was done, both within-subject factor and group and between-subject factor. The results revealed a main effect of the group $[F(2,42)=5.54, p<0.01]$. There was no significant interaction between thresholds at different modulation frequencies and groups $[F(10,210)=0.72$, $p>0.05]$. Duncan post hoc test results revealed a statistically significant difference between the musicians and non-musicians, whereas there was no statistically significant difference between the violinists and vocalists. Overall musicians performed better than non-musicians.

\section{Discussion}

The present study reveals no significant difference between violinists and vocalists in their temporal processing abilities. However, a significant difference was noted between musicians and non-musicians. The results are in consonance with results of past studies $[10,12,30]$ which report that temporal processing abilities are better or superior in musicians compared to non-musicians. The better performance of musicians can be attributed to the fact that music exposure helps develop auditory pathways for detecting fine modulations in intensity, frequency, or duration of a signal, aspects which are important in facilitating speech perception in noisy environments $[10,12,14,30]$.

Further, since no statistically significant difference in temporal processing was noted between violinists and vocalists, one needs to be a little circumspect in directly comparing the present results with those obtained previously. There are three reasons. First, the tests previously used by various researchers to compare auditory processing within musicians have gauged different aspects of auditory processing - such as the smallest detectable frequency difference as assessed by Nikjeh [21] using difference limens for frequency (DLFs) - whereas we have focused only on temporal processing. Second, the categories of musicians used by other researchers span a broad range; since each musical instrument has its own distinctive features, one 


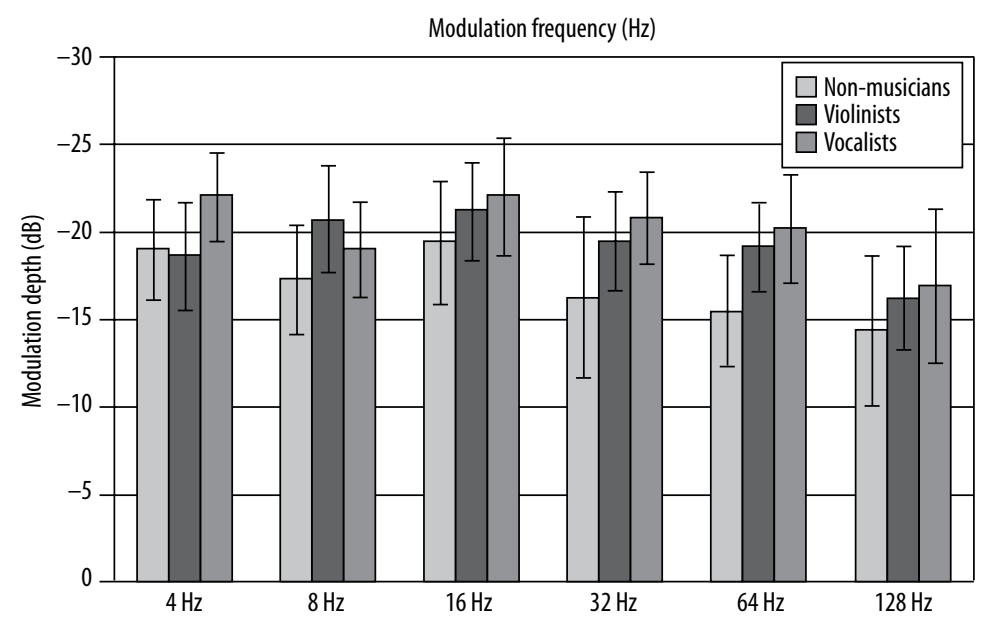

Figure 4. Mean modulation detection thresholds of SAM noise $( \pm 1$ SD) at six modulation frequencies for non-musicians, violinists, and vocalists

instrument cannot be directly compared with another. Third, to the best of our knowledge, until now no studies have been conducted between violinists and vocalists using psychoacoustic tests like GDT, DDT, DPT, and modulation detection thresholds for SAM noise.

Nevertheless, putting aside the above three reasons, an attempt can be made to broadly compare our findings with similar studies. Our findings are in partial agreement with Nikjeh [21] who used DLFs and reported slightly better, though not significant, pitch production in vocal musicians than instrumental musicians (brass, wind, or strings); overall, however, there was no significant difference in pitch perception and pitch production accuracy between musicians. In a different category of musicians, Kishon-Rabin et al. [18] reported a significant difference in frequency discrimination thresholds (using DLFs) between classical musicians and contemporary musicians. Seppanen et al. [19] also reported a significant difference in mismatch negativity (MMN), which assesses pre-attentive acoustic discrimination, between musicians who prefer aural strategies to practice and those who use other strategies. Halwani et al. [31] have reported that singers have a larger tract volume in the left dorsal and ventral arcuate fasciculus compared to instrumentalists, although there is no significant difference between the two. They further conclude that musicians, especially singers, can be used as a model to demonstrate structural as well as functional adaptations of the auditory - motor system by showing structural differences between the brains of those engaged in specific types of music training (vocal versus instrumental).

Statistically, the results of the present study provide no firm conclusion on whether a vocalist or instrumentalist will have better temporal processing abilities. Considering all the tests, however, it is seen that out of the all psychoacoustic tests (GDT, DDT, DPT, and SAM detection thresholds at 6 modulation frequencies), vocalists performed better in GDT test and at 5/6 modulation frequencies in modulation detection thresholds for SAM noise, based on which one could infer that vocalists perform slightly better than violinists. Also, since GDT and SAM detection thresholds are better in vocalists and DDT better in violinists, it can be inferred that vocal or violin training each probably enhances certain temporal processing abilities. Unfortunately, the results do not give a clear pointer as to which form of musical training (vocal or instrumental) might be used as a potential therapy for those who have poor perception of speech in adverse listening conditions. Further studies are needed to investigate whether particular types of musical training could be called upon to improve specific temporal processing abilities.

\section{Conclusions}

Based on the results of the present study, one can conclude that the degree to which musical training enhances temporal processing ability is about the same, irrespective of training method or type of music being learnt. However, to come to a strong conclusion, further research tapping other auditory processes such as those related to pitch, loudness, etc., and encompassing other categories of musicians is required.

\section{Acknowledgements}

We would like to thank the All India Institute of Speech and Hearing, Mysore, for providing facilities to conduct this research. We would also like to thank our participants for their time and both reviewers for valuable comments and suggestions.

\section{References:}

1. Shinn JB. Temporal processing: the basics. Hear J, 2003; 56(7): 52.

2. Minifie F. Speech acoustics. In: Minifie T, Hixon T, Williams F (eds.), Normal Aspects of Speech, Hearing and Language 1973; Englewoods Cliffs (NJ): Prentice-Hall.
3. Schneider BA, Pichora-Fuller K. Age-related changes in temporal processing: implications for speech perception. Semin Hear, 2001; 22(3): 227-39.

4. Lisker L. Closure duration and the voiced-voiceless distinction in English. Language, 1957; 33: 42-9. 
5. Lisker L, Abramson AS. A cross-language study of voicing in initial stops: acoustical measurements. Word, 1964; 20: 384-422.

6. Murthy. Closure duration as a cue to stop consonant voicing: a developmental study in 3-6 years old Kannada speaking children. JISHA, 1993; 8: 12-21.

7. Fischer-Jorgensen E. Temporal relation in consonant vowels syllables with stop consonant based on Danish material. In: Lindblom B, Ohman S (eds.), Frontiers of Speech Communication Research, 1979; Academic Press, Inc., London.

8. Zue VW. Acoustic characteristics of stop consonant: a controlled study. Lincoln Laboratory Technical Report, 1976; No. 523.

9. Mohamadkhani G, Nilforoushkhoshk MH, Mohammadi AZ, Faghihzadeh S, Sepehrnejhad M. Comparison of gap in noise test results in musicians and non-musician controls. Audiology, 2010; 19(2): 33-8.

10. Monteiro RA, Nascimento FM, Soares CD, Ferreira MD. Temporal resolution abilities in musicians and non-musicians. Int Arch Otolaryngol, 2010; 14(3): 302-8.

11. Nascimento FM, Monteiro RA, Soares C, Ferreira MD. Temporal sequencing abilities in musicians violinists and non-musicians. Intl Arch Otorhinolaryngol, 2010; 14(2): 217-24.

12. Rammsayer T, Altenmuller E. Temporal information processing in musicians and non-musicians. Music Percept, 2006; 24: 37-48.

13. Thomas OT, Rajalakshmi K. Effect of music training on temporal resolution abilities and speech perception in noise. Unpublished Masters dissertation 2011; University of Mysore, Mysore.

14. Rana B, Juneja A, Sinha S, Rajalakshmi K. Comparison of temporal resolution abilities in elderly musicians and non-musicians with hearing loss. Proceedings of International Symposium of Frontiers of Research on Speech and Music, 2014: 21-5.

15. Peretz I. The Nature of Music from a Biological perspective. Cognition, 2006; 100: 1-32.

16. Wolfe J. Speech and music, acoustics and coding, and what music might be 'for'. Proceedings of the $7^{\text {th }}$ International conference on Music perception and cognition, Sydney, Stevens K, Burnham D, McPherson G, Schubert E, Renwick J, (eds.), 2002: 10-13.

17. Wolfe J. Speech and music: acoustics, signals and the relation between them. Proceedings of the inaugural International conference on Music communication science, Sydney, Australia. December 2007; 176-9.
18. Kishon-Rabin L, Amir O, Vexler Y, Zaltz Y. Pitch discrimination: are professional musicians better than nonmusicians? J Basic Clin Physiol Pharmacol, 2001; 12: 125-43.

19. Seppänen MS, Brattico E, Tervaniemi M. Practice strategies in musicians modulate the neural processing and learning of sound-patterns. Neurobiol Learn Mem, 2007; 87: 236-47.

20. Jayakumar H, Gore M. Temporal Resolution in Musicians and Non musicians. Unpublished Masters dissertation 2010; University of Bangalore, Bangalore.

21. Nikjeh DA. Vocal and instrumental musicians: electrophysiologic and psychoacoustic analysis of pitch discrimination and production. Graduate School Theses and Dissertations 2006; University of South Florida. Paper 2646.

22. Spiegel MF, Watson CS. Performance on frequency-discrimination tasks by musicians and non-musicians. J Acoust Soc Am, 1984; 76: 1690-5.

23. American National Standards Institute. Maximum permissible ambient noise levels for audiometric test rooms (Rev. ed.) (ANSI S3.1-1999) 2003; New York.

24. Carhart R, Jerger JF. Preferred method for clinical determination of pure-tone thresholds. J Speech Hear Disord, 1959; 24: 330-45.

25. Rajashekar B, Vyasamurthy MN. Development and standardization of a picture SRT test for adults and children in Kannada. Unpublished Master's dissertation 1976; University of Mysore, Mysore.

26. Yathiraj A, Vijayalakshmi CS. Phonemically balanced word list in Kannada. Developed in Department of Audiology, AIISH, 2005; Mysore.

27. Levitt H. Transformed up-down methods in psychoacoustics. J Acoust Soc Am, 1971; 49(2): Suppl 2: 467.

28. Gauri DT, Manjula P. Development of Norms on Duration Pattern Test. Unpublished Masters dissertation 2003; University of Mysore, Mysore.

29. Grassi M, Soranzo A. MLP: A MATLAB Toolbox for Rapid and Reliable Auditory Threshold Estimations 2009.

30. Sangamanatha AV, Fernandes J, Bhat J, Srivastava M, Udupa SP. Temporal resolution in individuals with and without musical training. JISHA, 2012; 26(1): 27-35.

31. Halwani GF, Loui P, Rüber T, Schlaug G. Effects of practice and experience on the arcuate fasciculus: comparing singers, instrumentalists, and non-musicians. Front Psychol, 2011; 2: 156 . 